\title{
Performance of Amaranthus (Amaranthus spp.) Genotypes for Growth, Herbage Yield and Seed Yield in Prayagraj Agro-climatic Conditions
}

\author{
Blessina Pagidipally* and Samir E. Topno \\ Department of Horticulture, Naini Agricultural Institute, SHUATS, \\ Prayagraj Allahabad, U.P., India \\ *Corresponding author
}

\section{A B S T R A C T}

Keywords

Amaranthus, Varieties, Yield

Article Info

Accepted:

12 January 2021

Available Online:

10 February 2021
A field experiment entitled "Performance of Amaranthus genotypes for growth, herbage yield and seed yield in Prayagraj Agro-Climatic condition" was carried out at research field, Department of Horticulture, Naini Agricultural Institute, Sam Higginbottom University of Agriculture, Technology and Sciences, (Deemed-to-be University), Prayagraj, during the Kharif season of (2018-2019). Five plants were selected randomly from each plot and were tagged and maintained as observational plants for recording their growth and yield characters of Amaranthus. The Experiment was laid out in a Randomized Block Design with 15 treatments and 3 replications. Results revealed that the maximum Seed yield $(\mathrm{kg} / \mathrm{ha})$ was observed in $\mathrm{T}_{10}:$ Farmer variety (Tirupati) $(17.58 \mathrm{~kg} / \mathrm{ha})$ influenced most of the characteristics significantly and recorded the highest values of plant height $(35.10 \mathrm{~cm})$, number of leaves per plant (50.90), Number of branches per plant (4.40), leaf length $(11.47 \mathrm{~cm})$, Days to clipping (51.67), Days to first flowering (91.87), Days to first seed maturity (102.83), Spike length $\left(13.23 \mathrm{~cm}^{2}\right)$, Herbage yield per plant $(77.89 \mathrm{~g})$, Herbage yield per plot $(2.94 \mathrm{~kg})$, Herbage yield per ha $(17.58 \mathrm{t} / \mathrm{ha})$ and Seedyield per plant $(6.07 \mathrm{~g})$, per plot $(42.47 \mathrm{~g})$, per hectare $(232.55 \mathrm{~kg} / \mathrm{ha})$.

\section{Introduction}

Amaranthus (Amaranthus spp.), 2n=34 belongs to family Amarathaceae. Amarnathus is from Greek meaning "not to wither" and refers to the persistent flower spike. It is high in Vitamin $\mathrm{C}$, Calcium, Iron and other minerals. The nutritive value for $100 \mathrm{~g}$ of amaranthus has Moisture $91.6 \mathrm{~g}$, Protein 2.46g, Minerals $0.6 \mathrm{~g}$, Fibre $9.6 \mathrm{~g}$, Carbohydrates $4.02 \mathrm{~g}$, Energy $23 \mathrm{~K}$ Cal, Calcium $510 \mathrm{mg}$, Phosphorous $50 \mathrm{mg}$, Iron 2.32g, Thiamine $0.027 \mathrm{mg}$, Riboflavin $0.158 \mathrm{mg}$,Niacin $0.658 \mathrm{mg}$, Vitamin C 43.3 mg. India is the world's second largest producer of vegetables next to China. According to estimation, India produces 87.50 million tonnes of vegetables from an area of 5.80 million hectares. Amaranthus belong to the family Amaranthaceae and genus Amaranthus. The family Amranthaceae comprises 65 genera and 850 species. The genus Amaranthus includes 56 species. The important species of leafy amaranthus are: $A$. 
tricolor, A dubius, A. lividus, A. blitum, A. tritis, A. spinosus, A. virdius and A.gracizans. The most common and popular grain Amaranthus species are A. hypochondriacus, A. cruentus and $A$. caudatus.

One of the reasons there has been recent interest in amaranth is because of its useful nutritional qualities. The grain has 12 to $17 \%$ protein, and is high in lysine, an essential amino acid in which cereal crops are low. Amaranth grown at Arlington, WI in 1978 had protein levels of 16.6 to $17.5 \%$. The grain is high in fiber and low in saturated fats, factors which contribute to its use by the health food market. Recent studies have linked amaranth to reduction in cholesterol in laboratory animals.

Thus, India shares about $12 \%$ of world's output of vegetables (Thamburaj and Singh, 2001). In India, it is cultivated in an area of 2500 hectares with an annual production of 50,000 tonnes.

The organics are the indigenous source of nutrients which can help in increasing production and productivity along with improvement in soil physical conditions. Use of such organic materials, which are being wasted in large amounts without proper use can help in reducing cost of cultivation, increasing productivity and improving soil as well as human and livestock health. Various organic manures so far recognized in this group are green manures, rural/urban compost, farm yard manure, vermicompost, liquid organic manure etc.

\section{Materials and Methods}

The present experiment "Performance of Amaranthus genotypes for Growth, Herbage yield and seed yield in prayagraj agroclimatic conditions" was donein Horticulture research field, Department of Horticulture,
Naini Agricultural Institute, SHUATS, Prayagraj region was conducted during the year 2018-2019. The varieties used for the experiment are farmer varieties which were collected from local areas of Telungana and Andhra Pradesh. The observations were recorded on five randomly selected plants per replication was conducted in Randomized block design (RBD) with 15 treatments and 3 replications.

The data collected on different parameters during the course of investigation were subjected to statistical analysis as per method of analysis of variance (Panse and Sukhatme 1957).The significance and non - significance of the treatment effect was judged with the help of ' $F$ ' variance ratio test. Calculated ' $F$ ' value was compared with the table value of ' $F$ ' at $5 \%$ level of significance. If calculated value exceeds the table value, the effect was considered to be significant. The significant differences between the means were tested critical differences at $5 \%$ level of significance.

\section{Results and Discussion}

The detail pertaining to the research finding were presented and summarized below in this chapter.

The maximum plant height $(35.10 \mathrm{~cm})$ was observed in the treatment $\mathrm{T}_{\mathbf{1 0}}$ : Farmer variety (Tirupathi) and the minimum plant height $(18.13 \mathrm{~cm})$ was observed in Treatment $T_{1}$ : (Rangareddy). The maximum number of leaves (50.90) was observed in the treatment $\mathrm{T}_{10}$ : Farmer variety (tirupathi) and the minimum number of leaves (20.42) was observed in Treatment $\mathrm{T}_{1}$ : (Rangareddy). The highest number of branches was found in treatment $\mathrm{T}_{10}(9.30)$ at $45 \mathrm{DAS}$ and the lowest number of branches was found in treatment $\mathrm{T}_{9}$ : (5.87) Farmer variety (Eluru) (Table 1). 
Table.1

\begin{tabular}{|c|c|c|c|c|c|c|c|c|c|c|c|c|c|c|}
\hline Eี & Treatment combination & 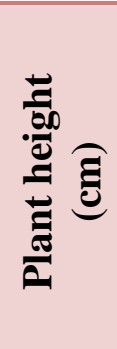 & 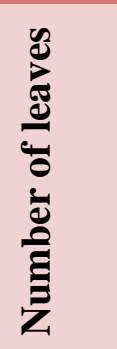 & 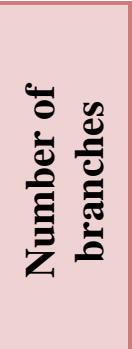 & 祥 & 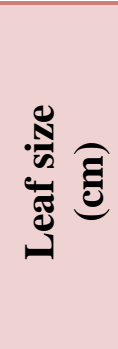 & 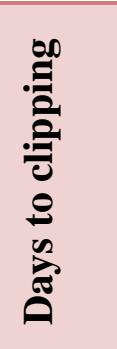 & 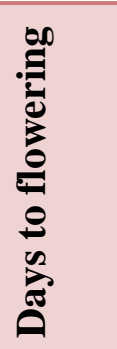 & 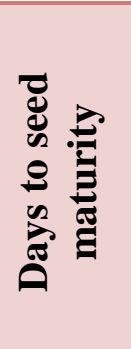 & 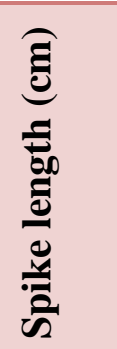 & 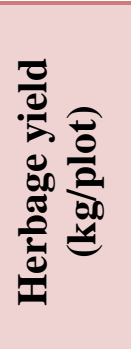 & 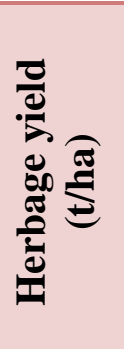 & 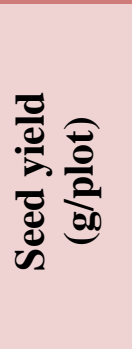 & 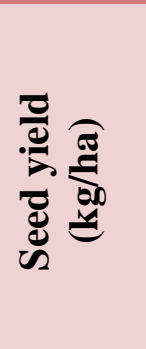 \\
\hline $\mathbf{T}_{1}$ & Farmer variety (Rangareddy) & 18.13 & 26.47 & 2.33 & 12.93 & 7.83 & 57.67 & 80.73 & 91.80 & 7.93 & 1.44 & 9.63 & 15.63 & 103.69 \\
\hline $\mathbf{T}_{2}$ & Farmer variety (Warangal) & 21.37 & 31.50 & 2.70 & 15.77 & 7.33 & 55.00 & 83.80 & 96.73 & 9.00 & 1.70 & 13.57 & 16.57 & 109.43 \\
\hline $\mathbf{T}_{3}$ & Farmer variety (Garla) & 25.33 & 44.50 & 3.13 & 13.80 & 7.80 & 54.33 & 79.00 & 95.30 & 10.17 & 2.43 & 14.59 & 28.23 & 97.24 \\
\hline $\mathbf{T}_{4}$ & $\begin{array}{ll}\text { Farmer } & \text { variety } \\
\text { (Kesamuobram) } & \end{array}$ & 18.83 & 29.30 & 2.53 & 15.57 & 9.23 & 53.33 & 79.13 & 92.07 & 8.37 & 1.59 & 13.63 & 18.43 & 100.41 \\
\hline $\mathbf{T}_{5}$ & Farmer variety (Nekonda) & 25.83 & 35.20 & 3.17 & 15.37 & 8.27 & 55.33 & 84.30 & 99.87 & 11.10 & 1.95 & 12.48 & 32.20 & 112.65 \\
\hline $\mathbf{T}_{6}$ & AMVAR1 (Check) & 23.97 & 33.27 & 2.73 & 14.97 & 7.10 & 55.67 & 81.67 & 92.70 & 9.67 & 1.81 & 15.29 & 22.17 & 168.42 \\
\hline $\mathbf{T}_{7}$ & Farmer variety (Bhimavaram) & 27.20 & 44.47 & 3.30 & 19.57 & 7.87 & 51.67 & 77.50 & 95.00 & 11.47 & 2.46 & 14.62 & 32.90 & 128.58 \\
\hline $\mathbf{T}_{8}$ & $\begin{array}{l}\text { Farmer } \\
\text { (Kumaradevam) }\end{array}$ & 28.57 & 46.80 & 3.67 & 17.27 & 8.57 & 53.00 & 87.03 & 101.47 & 12.37 & 2.70 & 8.53 & 35.70 & 136.68 \\
\hline $\mathbf{T}_{9}$ & Farmer variety ( Eluru) & 20.77 & 41.93 & 2.37 & 16.20 & 7.30 & 51.33 & 76.00 & 90.67 & 8.57 & 2.21 & 16.56 & 17.73 & 176.84 \\
\hline $\mathbf{T}_{10}$ & Farmer variety (Tirupati) & 35.10 & 50.90 & 4.40 & 25.33 & 11.47 & 51.67 & 75.40 & 88.47 & 13.23 & 2.94 & 17.58 & 42.47 & 232.55 \\
\hline $\mathbf{T}_{11}$ & Farmer variety (Guntur) & 26.50 & 43.20 & 2.87 & 20.43 & 9.17 & 51.33 & 82.20 & 95.67 & 11.87 & 2.31 & 14.21 & 34.77 & 120.48 \\
\hline $\mathbf{T}_{12}$ & $\begin{array}{l}\text { Farmer } \\
\text { (Rajahmundry) }\end{array}$ & 25.03 & 39.10 & 2.57 & 15.47 & 7.30 & 52.00 & 76.83 & 93.20 & 10.53 & 2.07 & 9.42 & 28.70 & 95.57 \\
\hline $\mathbf{T}_{13}$ & Farmer variety (Kurnool) & 31.50 & 49.60 & 4.13 & 16.33 & 6.27 & 51.00 & 89.07 & 101.80 & 12.77 & 2.91 & 10.79 & 30.47 & 104.83 \\
\hline $\mathbf{T}_{14}$ & Farmer variety (Nellore) & 12.93 & 23.77 & 2.07 & 10.90 & 7.00 & 55.67 & 91.87 & 102.83 & 7.37 & 1.43 & 8.43 & 13.53 & 89.01 \\
\hline $\mathbf{T}_{15}$ & $\begin{array}{l}\text { Farmer } \\
\text { (Visakapatanam) }\end{array}$ & 25.20 & 40.53 & 2.70 & 16.73 & 7.63 & 54.33 & 84.30 & 93.90 & 9.43 & 2.27 & 10.39 & 22.40 & 110.46 \\
\hline & F-Test & 3 & 3 & 3 & 3 & $\mathbf{S}$ & $\mathbf{S}$ & $\mathbf{S}$ & $\mathbf{S}$ & $\mathbf{S}$ & $\mathbf{S}$ & $\mathbf{S}$ & $\mathbf{S}$ & $\mathbf{S}$ \\
\hline & S.Ed. (+) & 1.252 & 1.423 & 0.354 & 0.922 & 1.269 & 1.379 & 1.654 & 1.878 & 0.240 & 0.100 & 0.309 & 5.99 & 0.703 \\
\hline & C. D. at 0.5 & 0.611 & 0.695 & 0.173 & 0.450 & 0.620 & 0.673 & 0.808 & 0.917 & 0.117 & 0.049 & 0.151 & 2.928 & 0.343 \\
\hline
\end{tabular}


The highest leaf length was found in treatment $\mathrm{T}_{\mathbf{1 0}}$ : Farmer variety (Tirupathi) $(11.47 \mathrm{~cm})$ and the lowest leaf length was found in treatment $T_{13}:(7.00 \mathrm{~cm})$ Farmer variety (Nellore). The minimum days to clippings is about (39.33 $1^{\text {st }}$ clipping) was found in treatment $\mathrm{T}_{10}$ :Farmer variety (Tirupathi) and maximum in $\mathrm{T}_{1}$ :(Rangareddy) (46.67days) and minimum days to $2^{\text {nd }}$ clipping was found in treatment $T_{11}$ (51.33days) and highest in $\mathrm{T}_{1}$ (Rangareddy) (57.67days). Minimum days to first flowering was about (75.40days) was found in Treatment $\mathrm{T}_{10}$ (Tirupathi) and maximum was recorded about (91.87days) in Treatment $\mathrm{T}_{14}$ (Nellore). The highest spike length was found in treatment $\mathrm{T}_{10}$ :Farmer variety (Tirupathi) $(13.23 \mathrm{~cm})$ and the lowest spike length was found in treatment $T_{14}$ : $(7.37 \mathrm{~cm})$ Nellore variety.

Highest herbage yield per plant $(77.89 \mathrm{~g})$, per plot $(2.94 \mathrm{~kg})$ per hectare $(17.58 \mathrm{t} / \mathrm{ha})$ was recorded in treatment $\mathrm{T}_{10}$ :Farmer variety (Tirupathi) and the and lowest herbage yield per plant $(58.56 \mathrm{~g})$,per plot $(1.43 \mathrm{~kg})$, per hectare $(8.43 \mathrm{t} / \mathrm{ha})$ was obtained in treatment $\mathrm{T}_{14}$ (Nellore variety). Highest seed yield per plant $(8.37 \mathrm{~g})$, per plot $(42.47 \mathrm{~g})$, per hectare $(232.55 \mathrm{~kg} / \mathrm{ha})$ was recorded in treatment $\mathrm{T}_{\mathbf{1 0}}$ :Farmer variety (Tirupathi) and lowest seed yield per plant (1.93g), per plot(13.53g), per hectare $(89.01 \mathrm{~kg} / \mathrm{ha})$ obtained in treatment $\mathrm{T}_{14}$ : Farmer variety (Nellore).

On the basis of present investigation it is concluded that the treatment $\mathrm{T}_{\mathbf{1 0}}$ :Farmer Variety (Tirupathi) was found to be the best variety in respect of plant growth and yield parameters and showed maximum gross return(204175 Rs/ha), net return(132358 Rs/ha) and benefit: cost ratio i.e., (1:2.84). These findings are based on one season trail, therefore, further evaluation trails are needed to substantiate the findings.

\section{References}

Deepika Chandravanshi, Pravin Kumar Sharma and HG Sharma (2018). Evaluation and characterization of leafy vegetables (Amaranthus spp.) grown in Chhattisgarh: A review. International Journal of Chemical Studies 2018; 6(3): 697-704

Devadas, V.S., Gopal Krishnan, P.K. and Peter, K.V. (1992). Genetic divergence in vegetable amaranthus. South Indian Hort. 40: 16-20.

Dewan M. N. N., Haq M. E., Hasan M. M., Hossain M. S.and Tareq M. Z. (2017) Genotype $\mathrm{x}$ environment interaction effects on the field performance of stem amaranth (Amaranthus tricolor L.). Bangladesh J. Pl. Breed. Genet., 30(1): 21-31.

Dhangrah, V. K. Joydip Mandal (2008) Studies on some growth attributes of vegetable amaranth. Orissa Journal of Horticulture; 36: 2, 132-135.

Fisher, R.A. (1949).Statistical method for research workers, ISBN-0-05-002170-2.

Jamriska, P. (1996). The influence of cultivar on seed yield of amaranth (Amaranthus sp.). [Slovakian] Rostlinna Vyroba; 42: 3, 109-114.

Panse, V. G. and Sukhatme, P.V. (1957), Statistical Methods for Agricultural Workers ( $2^{\text {nd }}$ Edn.), Indian Council of Agriculture Research, New Delhi,381p.

Revanappa and Madalageri, B.B. (1998).Genetic variability studies regarding quantitative and qualitative traits in Amaranthus. Karnataka Journal of Agriculture Science.11:1, 139-142.

Singh, D. K. (2000) Response of paclobutrazol on growth, yield and quality of amaranth (Amaranthus tricolor). Vegetable Science; 27: 2, 201 202

Talukder, M. S. A. Islam, M. S. Hossain, M. 
M. Kundu, R. Hossain, S. M. S. (2004) Effects of plant density and cultivars on the green yield and yield components of some stem amaranthus (Amaranthus tricolour L.). Journal of Subtropical Agricultural Research and Development; 2: 1, 10-16.

Tryak, I. (2006). Priming and storage of amaranth seeds: effects of plant growth regulators on germination performance at low temperature. Seed Science and Technology; 2006. 34: 1, 169-179.

Patil, T. R. Mahalle, A. M. Kagane, B. V. Deshmukh, M. P. (2002) Physiological analysis of growth and yield of Amaranthus (Amaranthus hypochondriacus). Journal of Soils and Crops; 12: 1, 36-40.

\section{How to cite this article:}

Blessina Pagidipally and Samir E. Topno. 2021. Performance of Amaranthus (Amaranthus spp.) Genotypes for Growth, Herbage Yield and Seed Yield in Prayagraj Agro-climatic Conditions. Int.J.Curr.Microbiol.App.Sci. 10(02): 1311-1315.

doi: https://doi.org/10.20546/ijcmas.2021.1002.155 